INTERNATIONAL JOURNAL OF RESEARCHES IN BIOSCIENCES, AGRICULTURE AND TECHNOLOGY (c) VISHWASHANTI MULTIPURPOSE SOCIETY (Global Peace Multipurpose Socie ty) R. No. MH-659/13 (N) www.vmsindia.org

\title{
PHARMACOGNOSTIC EFFECTIVENESS OF BALANITES AEGYPTIACA (L.) DELILE
}

\author{
K. M. Salve \\ Pemraj Sarda College, Ahmednagar, Savitribai Phule Pune University, Pune (M.S.). \\ skbotany@gmail.com
}

\begin{abstract}
Balanites aegyptiaca (L.) Delile a tree species belonging to Zygophyllaceae (Balanitaceae) more commonly known as Angarvriksha, Balanite, Desert date, Soapberry tree, Thorn tree and Egyptian balsam tree is found in most arid, semiarid to sub humid and hot dry areas has splendid medicinal properties. Investigations on Pharmacognostic effectiveness of leaves of Balanites aegyptiaca (L.) De lile was carried out using various parameters like organole ptic evaluation, histochemistry, preliminary phytochemical investigation and percentage extractives to detect the presence of active components. Pharmacognostic study revaled many positive results for secondary chemical constituents except protein. Highest percentage extractives were observed in distilled water followed by acetone.

Keywords: Balanites aegyptiaca (L.) De lile, Pharmacognostic effectiveness, His tochemistry, Phy to chemistry.
\end{abstract}

\section{Introduction}

Indian history of medicinal plants is dated back 3500 BC. The curative properties of plant have been mentioned in Suktas of Rigveda and Atharveda. Ayurveda has also described lots of plants with their therapeutic properties (Kirtikar and Basu 1999; Khare 2007). Balanites aegyptiaca (L.) Del. is belongs to family Zygophyllaceae (Balanitaceae) commonly known as Angarvriksha, Balanite, Hingan, Dese rt date, Soapberry tree, Thorn tree and Egyptian balsam tree Anonymous (1955). The name Balanites was given by Alire Delile in 1813 derived from Greek for fruit resemble acorn and aegyptica means, this plant is extensively found in Egypt Gupta et al (2012). It is one of the most common but neglected wild plant species of the dry land areas of Africa and South Asia (Hall and Walker 1991, Okia et al 2011). In India, it is particularly found in Rajasthan, Gujarat, Madhya Pradesh, Maharashtra and Deccan. The drug Balanites has been used in indigenous system of medicine since long time. It cures vatta and kapha. Different parts of plant have been mentioned as useful to treatments of skin diseases (Unani), lecoderma, boils. Fruit has anthelmintic, analgesic, anti - dysenteric properties, it cures ulcer (Ayurveda), rat bits. According to Sushruta, the plant is prescribed in the treatment of snake bites. It also used as a detergents (pulp of fruits) and bark is as poison fish. The decoction of roots is tonga emetic. The oil is used as a remedy for sleeping sick and as purgative Barley (1962). In folk medicine, the brown outer rind of fruit is used in the treatment of skin diseases, root bark in treatment of malarial and fruit extract as hypoglycemic agent (Katewa et a1., 2004; Koch et al., 2005; Gad et al., 2006). Known its evident capacity as medicinal plant Balanite is not much investigate.

\section{Material and Methods}

The plant material of Balanites aegyptiaca (L.) Del. was collected from the Ahmednagar - Solapur, (M.S.) highway and used for the present study. Analysis was carried for leaf as medicinally efficient organ. Pharmacognostic study included organoleptic evaluation, Histochemistry, Phytochemistry and Percentage extractives Khandelwala (2005). Organoleptic evaluation was carried out obse rve and record macroscopic characters Wallis (1985). Histochemistry was carried out to localize the presence of secondary metabolites and other chemical content Johansen (1940), Krishnamurty (1988). Phytochemistry was carried out for detection of secondary metabolites in both water and alcohol extracts Harborne (1973). Percentage extractives were re corded in diffe re nt solvent systems along with water.

\section{Results and Discussion Organoleptic evaluation:}

Shape: oval, obtuse or broadly pointed, Size: Length 1 to $5 \mathrm{cms}$ and Breadth $1.5 \mathrm{cms}$, Colour: External Light Green and Internal dark Green, Odour: Characteristic, Taste: Bitter, Extra features: Surface glabrous, Texture: Thin and leathery (Table 1-5)

The objective of Pharmacognosy establishes the relationship between chemical constituents of drugs and their therapeutic effectiveness which help to standardize the plant Trease and Evans (2002). The histochemical results revealed localization of Tannins, Starch and Alkaloids ranging from epidermis to mid rib 
region. It also showed presence of sugar and saponin throughout the section which can be confirmed by work done by Hardman and Sofowora (1970). Phytochemistry revealed similar re sults for alkaloid as reported by Saboo et al. (2014). The percentage extractives in different six solvents showed minimum percentage extractives $10 \%$ was in Diethyl ether and maximum $80 \%$ in Distilled wate $r$ followed by Acetone. Overall histochemical and phytochemical study showed positive results for secondary metabolites similarly reported by other researchers like Salwa and El Hadidi (1988); Saharan et al. (2008); Hammouda et al (2005); Chothani and Vaghasiya (2011) and Saboo et al. (2014).

Table 1- His to chemis try:

\begin{tabular}{|c|c|c|c|}
\hline Sr. No. & Test & Location & Result \\
\hline 1 & Tannin & Epidermis, Palisade cells & $+\mathrm{ve}$ \\
\hline 2 & Starch & Epidermis, Midrib region, Trichomes & $+\mathrm{ve}$ \\
\hline \multirow[t]{3}{*}{3} & \multicolumn{3}{|l|}{ Alkaloids } \\
\hline & Wagner's & Palisade and Midrib region & $+\mathrm{ve}$ \\
\hline & $\begin{array}{l}\text { Mayer's } \\
\text { Dragendorff's }\end{array}$ & $\begin{array}{l}\text { Epidermis and Midrib region } \\
\text { Palisade and Midrib region }\end{array}$ & $\begin{array}{l}\text { +ve } \\
\text { +ve }\end{array}$ \\
\hline 4 & Sugar & Palisade & $+\mathrm{ve}$ \\
\hline 5 & Saponins & Throughout section & $+\mathrm{ve}$ \\
\hline 6 & Lipid & Epidermis & $+\mathrm{ve}$ \\
\hline 7 & Protein & - & -ve \\
\hline
\end{tabular}

Table 2- Phytochemistry:

Table 2.1 Distilled wate $r$ ex tractive s:

\begin{tabular}{|ll|l|l}
\hline $\begin{array}{l}\text { Sr. } \\
\text { No. }\end{array}$ & Test & Reagent & Result \\
\hline 1 & Tannin & Aced ic FeCl3 & +ve \\
\hline 2 & Starch & $\mathrm{I}_{2} \mathrm{KI}$ & -ve \\
\hline 3 & Sugar & Be nedicts & $+\mathrm{ve}$ \\
\hline 4 & Saponins & $\begin{array}{l}\text { Distilled } \\
\text { Water } \\
\text { Be nzene }+10 \% \\
\text { NH }\end{array}$ & +ve \\
Anthro- \\
quinones
\end{tabular}

Table 2.2 - Alco holic extractives:

\begin{tabular}{|l|l|l|l|}
\hline Sr. No. & Test & Reagent & Result \\
\hline 1 & \multirow{3}{*}{ Alkaloids } & Wagner's & $+\mathrm{ve}$ \\
\cline { 3 - 4 } & & Mayer's & $+\mathrm{ve}$ \\
\cline { 3 - 4 } & & Dragendorff's & $+\mathrm{ve}$ \\
\cline { 3 - 4 } & Hager's & $+\mathrm{ve}$ \\
\hline 2 & Glycoside & Benzene & $+\mathrm{ve}$ \\
\hline 3 & Flavonoids & $\begin{array}{l}\text { conc. HCL + } \\
\text { mg turning }\end{array}$ & -ve \\
\hline
\end{tabular}

Table 3-Pe rcentage Extractives:

\begin{tabular}{l|l|c|c|c|c|}
\hline $\begin{array}{l}\text { Sr. } \\
\text { No. }\end{array}$ & $\begin{array}{l}\text { Solvent } \\
\text { used }\end{array}$ & $\begin{array}{l}\text { Weight of e mpty } \\
\text { porcelin dish 'A' } \\
\text { gms. }\end{array}$ & $\begin{array}{l}\text { Weight of porcelin dish } \\
\text { with extract 'B' gms. }\end{array}$ & $\begin{array}{l}\text { Weight of } \\
\text { extract } \\
\text { (gms.) }\end{array}$ & $\begin{array}{l}\text { Percentage } \\
\text { extractives }\end{array}$ \\
\hline 1 & Diethyl ether & 51.60 & 51.70 & 0.10 & 10 \\
\hline 2 & $\begin{array}{l}\text { Petroleum } \\
\text { ether }\end{array}$ & 52.90 & 53.30 & 0.40 & 40 \\
\hline 3 & $\begin{array}{l}\text { N- Butyl } \\
\text { alcohol }\end{array}$ & 51.50 & 51.68 & 0.18 & 18 \\
\hline 4 & Benzene & 47.51 & 47.80 & 0.29 & 29 \\
\hline 5 & Acetone & 59.10 & 59.15 & 0.50 & 50 \\
\hline 6 & $\begin{array}{l}\text { Distilled } \\
\text { Water }\end{array}$ & 47.20 & 48.00 & 0.80 & 80 \\
\hline
\end{tabular}

\section{Conclusion}

The histochemical and preliminary Phytochemical results of crude drug of Balanites reveals the presence of Tannins, Starch, alkaloids, glycosides, sugars, saponin and lipids which are useful in various preparations of drugs. Thus the standardization parameters like organoleptic evaluation, histochemistry, phytochemistry and percentage extractives of leaf assessed for the quality of plant material are also helpful for detection of adulteration. On account of these chemicals it can be concluded 
that investigations of the drug Balanite has importance in medicinal systems.

\section{References}

Anonymous (1955). Pharmacopoeia of India, Govt. of India Ministry of Health, Manager Publication, Delhi $1^{\text {st }}$ Edition.

Barley, S., (1962). Zygophyllaceae. In: Watt J M, Breyer-Brandwijk M G, editor. The Medicinal and poisonous plants of Southern and Eastern Africa. London: Livingstone Ltd., p. 1064.

Chothani, D. L. and Vaghasiva, H. U., (2011). A review on Balanites aegyptiaca Del (desert date): phytochemical constituents, traditional uses, and pharmacological activity. Phcog Rev. pp. 5562 .

Gad, M. Z., El-Sawalhi, M. M., Ismail, M. F., ElTanbouly, N. D., (2006). Biochemical study of the anti-diabetic action of the Egvptian plants Fenugreek and Balanites.Molecular \& Cellular Biochemistry 281, pp. 173-183.

Gupta, S. C., Shenoy, S. and Kotecha, M., (2012). Pharmacognostical and Phvtochemical evaluation of Balanites aegyptica De1. Stem Bark, International Research Journal of Pharmacy, 3(7): 169 -173.

Hall, J. B. and Walker, D. H., (1991). Balanites aegyptica Del. A Monograph, School of Agriculture and forest Sciences, Banger: University of Wales, pp. 1-12.

Hammouda, M., Is mail, S. I., Abdel-Azim, N. S. and Shams K. A., (2005). A Guide to Medicinal Plants in North Africa, IUCN (International Union for Conservation of Nature. p. 51.

Harborne, J. B., (1973). Phytochemical Methods a modern techniques of Plant analysis, first Publisher Chapman and Hall Ltd, London, pp. $15-18$.

Hardman, R. and Sofowora, E. A., (1970). Isolation and characterization of vamogenin from balanites aegyptiaca. Phytochemistry. 9:645-9.

Johansen, D. A., (1940) Plant Microtechniques, pp. 154.
Katewa, S. S., Chaudhary, B. L., Jain, A., (2004). Folk herbal medicines from tribal are a of Rajasthan, India. Journal of Ethnopharmacology 92 , pp. 41-46.

Kirtikar, K.R. and Basu, B. D., (1999). Indian Medicinal Plants Vol I, pp. 512 - 514.

Khandelwala, K. R., (2005). Practical Pharmacognosy: tech. and experiments, Nirali Prakashan, Pune, pp. 149- 53.

Khare, C.P., (2007). Indian medicinal plants: An illustrated dictionary. Springer. 77-8

Koch, A., Tamez, P., Pezzuto, J., Soejarto, D., (2005). Evaluation of plants used for anti malarial treatment by the Maasai of Kenya. Journal of Ethnopharmacology 101, pp. 95-99.

Krishnamurty, K. V., (1988). Methods in Plants His toche mis try, S. Viswanathan (Printers and Publication) Pvt Ltd.

Okia, C. A., Agea, J. G., Kimondo, J. M., Abohassan, R. A. A., Okiror, P., Obua, J. and Teklehaimanot, Z., (2011). Use and Management of Balanites aegyptiaca in Drylands of Uganda, Research Journal of Biological Sciences, 6(1): 15-24.

Saboo, S. S., Chavan, R. W., Tapadiya, G.G. and Khadabadi, S.S., (2014). An Important Ethnomedicinal Plant Balanite Aegyptiaca Del., International Journal of Phytopharmacy Vol. 4 (3), pp.75-78.

Saharan, V., Yadav, R. C. and Wiesman, Z. (2008). Balanites aegyptiaca (L.) Delile: A potential source of saponin. Curr Biotica. 2:1103 .

Salwa, A. M. and El Hadidi, M. N., (1988). Flavonoids of Balanites aegyptiaca (Balanitaceae) from Egypt. Plant Syst Evol. 160:153-8

Trease, G. E. and Evans, W. C., (2002). Pharmacognosy, 15th Edition, Bacillier Tindall London, pp. 150.

Wallis, T. E., (1985). Textbook of Pharmacognosy. CBS Publishers and Dis tributors, New Delhi., pp. 517-618. 